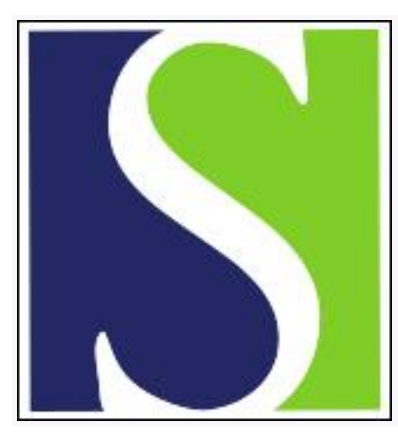

Scand J Work Environ Health 1981;7(1):45-50

https://doi.org/10.5271/sjweh.2567

Issue date: Mar 1981

Distribution and elimination of ${ }^{14} \mathrm{C}$-styrene in rat.

by Carlsson A

Key terms: ${ }^{14} \mathrm{C}$-styrene; distribution; elimination; exposure; metabolite; rat; styrene; tissue concentration

This article in PubMed: www.ncbi.nlm.nih.gov/pubmed/7313609

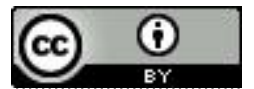




\title{
Distribution and elimination of ${ }^{14} \mathrm{C}$-styrene in rat
}

\author{
by Anders Carlsson, MD ${ }^{1}$
}

\begin{abstract}
CARLSSON A. Distribution and elimination of ${ }^{14} \mathrm{C}$-styrene in rat. Scand $j$ work environ health 7 (1981) 45-50. Male rats were exposed to about $45 \mathrm{ppm}$ of radioactively labeled styrene in the inspired air for $1-8 \mathrm{~h}$. The distribution and elimination of styrene and its metabolites in different organs and tissues were studied. To get an idea of the ratio between unmetabolized and metabolized styrene in organs and tissues, a supplementary study was performed in which five male rats were exposed to about $250 \mathrm{ppm}$ of radioactively labeled styrene. The largest amounts of styrene and its metabolites were found in the subcutaneous fat, and the concentration displayed a sharp rise during the first $4 \mathrm{~h}$ of exposure in comparison with the following $4 \mathrm{~h}$. The concentration of styrene and its metabolites in the cerebrum, cerebellum and muscles paralleled the arterial blood concentration throughout the entire period of exposure and amounted to about $70 \%$ of the arterial blood value. In the supplementary study an accumulation of styrene metabolites in subcutaneous fat was disclosed; it ranged from 15 to $20 \%$ during exposure.
\end{abstract}

Key terms: exposure, metabolites, styrene, tissue concentration.

About $3 \%$ of the styrene taken up in man is exhaled in an unchanged form via the lungs (7). About $95 \%$ is excreted in the urine as mandelic acid and phenylglyoxylic acid (2).

In rat styrene is mainly excreted as hippuric acid (12). About $3 \%$ of the radioactively labeled styrene administered to rat in a subcutaneous injection is exhaled in an unchanged form via the lungs, whereas the remainder is metabolized and excreted mainly via the urine (6).

In the present study rats were exposed to styrene in inspiratory air. The purpose was to study the distribution and elimination of styrene and its meta'bolites.

\section{Experimental design and methods}

Radioactively labeled styrene $\left(7-{ }^{14} \mathrm{C}\right)$, with a specific activity of $0.35 \mathrm{mCi} / \mathrm{mmol}$, was

1 Department of Occupational Health, National Board of Occupational Safety and Health, Solna, Sweden.

Reprint requests to: Dr Anders Carlsson, Department of Occupational Health, National Board of Occupational Safety and Health, S-171 84. Solna, Sweden. injected with a microliter syringe (Hamilton-Boyd, Switzerland) into a polyesterlaminated aluminium foil bag containing a known quantity of air. Male rats (SpragueDawley, $200 \mathrm{~g}$ ) were exposed to the mixture of styrene vapor and air for $1-8 \mathrm{~h}$ in a metabolism cage $(150 \mathrm{~mm}$ inner diameter, Kebo-Grave, Sweden). The air mixture from the aforementioned bag flowed via a teflon tube into the cage and then passed a flow meter (model $1350 \mathrm{~V}, \mathrm{AB}$ Max Sievert, Vällingby, Sweden) and a capillary tube which induced a constant flow of $0.45 \mathrm{l} / \mathrm{min}$. The concentration of styrene in the metabolism cage was analyzed with the charcoal sampling method (9). The air mixture contained $184 \pm 13$ (SD) $\mathrm{mg} / \mathrm{m}^{3}(43.5 \mathrm{ppm})$ of styrene.

After the exposure was concluded, some rats breathed ordinary air during a decay phase. Table 1 lists the exposure durations, decay phases and the number of rats exposed to styrene.

After the rats had been killed by luxa-. tion of the cervical spine, double samples were taken from organs and tissues for the assay of radioactively labeled styrene and radioactive metabolites. Samples were taken from the liver, kidneys, subcutane- 
ous fat, cerebrum, cerebellum, muscles, lungs, spleen, ischiadic nerve, and arterial blood. The arterial blood $(0.1-0.4 \mathrm{ml})$ was mixed with $1.5 \mathrm{ml}$ of Soluene-100 ${ }^{\circledR}$ (Packand Instrument $A B)$ : isopropanol (1:1) in glass scintillation vials (Packard). After 10-min digestion at room temperature, 0.5 $\mathrm{ml}$ of $35 \%$ hydrogen peroxide was added. After $60 \mathrm{~min}$ at room temperature, $15 \mathrm{ml}$ of $0.5 \mathrm{~N}$ hydrochloric acid: Insta-Gel ${ }^{\circledR}$ (Packard) (1:9) was added. The other samples, weighing $10-80 \mathrm{mg}$, were isolated and placed in glass scintillation vials containing $1 \mathrm{ml}$ of Soluene-350 ${ }^{\circledR}$ (Packard). They were then digested for $2-8 \mathrm{~h}$ at $+50^{\circ} \mathrm{C}$ before the addition of $9 \mathrm{ml}$ of scintillation liquid consisting of Permablend III $^{\circledR}$ (Packard) dissolved in toluene.

Table 1. Organ and tissue concentrations ( $\mathrm{nmol} / \mathrm{g}$ tissue) of styrene equivalents (styrene and its metabolites) in rat following exposure to a styrene concentration of $184 \mathrm{mg} / \mathrm{m}^{3}(43.5 \mathrm{ppm})$ in inspiratory air - Means \pm standard errors (determined from the mean of two samples for each rat) and the method error.

\begin{tabular}{|c|c|c|c|c|c|c|c|c|}
\hline \multirow[b]{2}{*}{ Organ } & \multicolumn{7}{|c|}{ Duration of exposure + time after exposure $(h)$} & \multirow{2}{*}{$\begin{array}{c}\text { Method error a } \\
(\% \text { of mean } \\
\text { value })\end{array}$} \\
\hline & $\begin{array}{c}1+0 \\
(\mathrm{~N}=5)\end{array}$ & $\begin{array}{c}2+0 \\
(N=4)\end{array}$ & $\begin{array}{c}4+0 \\
(N=3)\end{array}$ & $\begin{array}{c}8+0 \\
(N=3)\end{array}$ & $\begin{array}{c}1+1 \\
(N=4)\end{array}$ & $\begin{array}{c}1+3 \\
(N=4)\end{array}$ & $\begin{array}{c}1+6 \\
(N=3)\end{array}$ & \\
\hline Liver & $65 \pm 3$ & $68 \pm 2$ & $93 \pm 2$ & $123 \pm 14$ & $19 \pm 2$ & $12 \pm 1$ & $11 \pm 1$ & 2.4 \\
\hline Kidneys & $244 \pm 43$ & $609 \pm 58$ & $698 \pm 117$ & $728 \pm 162$ & $264 \pm 55$ & $125 \pm 31$ & $97 \pm 28$ & 15.8 \\
\hline Subcutaneous fat & $87 \pm 4$ & $134 \pm 10$ & $201 \pm 12$ & $215 \pm 25$ & $66 \pm 9$ & $22 \pm 2$ & $7 \pm 2$ & 8.0 \\
\hline Cerebrum & $16 \pm 1$ & $18 \pm 1$ & $28 \pm 4$ & $34 \pm 2$ & $9 \pm 1$ & $6 \pm 1$ & $5 \pm 1$ & 4.2 \\
\hline Cerebellum & $15 \pm 1$ & $21 \pm 1$ & $29 \pm 3$ & $36 \pm 3$ & $10 \pm 2$ & $6 \pm 1$ & $5 \pm 1$ & 4.5 \\
\hline Ischiadic nerve & $38 \pm 5$ & $52 \pm 3$ & $78 \pm 4$ & $103 \pm 15$ & $15 \pm 2$ & $9 \pm 1$ & $6 \pm 1$ & - \\
\hline Muscles & $19 \pm 1$ & $23 \pm 2$ & $29 \pm 6$ & $37 \pm 2$ & $9 \pm 2$ & $6 \pm 1$ & $7 \pm 1$ & 9.0 \\
\hline Lungs & $29 \pm 2$ & $36 \pm 2$ & $46 \pm 5$ & $68 \pm 9$ & $12 \pm 3$ & $12 \pm 4$ & $7 \pm 1$ & 5.0 \\
\hline Spleen & $23 \pm 1$ & $24 \pm 3$ & $34 \pm 6$ & $63 \pm 12$ & $10 \pm 2$ & $8 \pm 1$ & $6 \pm 1$ & 6.7 \\
\hline Blood & $26 \pm 2$ & $32 \pm 4$ & $39 \pm 5$ & $49 \pm 3$ & $10 \pm 1$ & $8 \pm 1$ & $7 \pm 1$ & 3.2 \\
\hline
\end{tabular}

a $S D=\left\{\left[\Sigma D^{2}-(\Sigma D)^{2} / n\right] / 2(n-1)\right\}^{1 / 2}$

Table 2. Mean organ and tissue concentrations of styrene (S) and its metabolites (M), specified as nanomoles of styrene equivalents per gram of tissue, in rat after exposure to a styrene concentration of $1,014 \mathrm{mg} / \mathrm{m}^{3}(240 \mathrm{ppm})$ in inspiratory air, the proportion of metabolites as percentage, and the error of the method for styrene.

\begin{tabular}{|c|c|c|c|c|c|c|c|c|c|c|c|}
\hline \multirow{3}{*}{ Organ } & \multicolumn{10}{|c|}{ Duration of exposure + time after exposure $(h)$} & \multirow{3}{*}{$\begin{array}{c}\text { Method error } \\
\text { for styrene a } \\
(\% \text { of mean } \\
\text { value })\end{array}$} \\
\hline & \multicolumn{2}{|c|}{$\begin{array}{c}0.25+0 \\
(N=1)\end{array}$} & \multicolumn{2}{|c|}{$\begin{array}{c}1+0 \\
(N=1)\end{array}$} & \multicolumn{2}{|c|}{$\begin{array}{c}4+0 \\
(N=1) \\
\end{array}$} & \multicolumn{2}{|c|}{$\begin{array}{c}8+0 \\
(N=1)\end{array}$} & \multicolumn{2}{|c|}{$\begin{array}{c}8+3 \\
(\mathrm{~N}=1) \\
\end{array}$} & \\
\hline & $S$ & $\mathrm{M}$ & $s$ & $M$ & $S$ & M & $s$ & $M$ & $S$ & $M$ & \\
\hline \multicolumn{12}{|l|}{ Liver } \\
\hline $\begin{array}{l}\mathrm{nmol} / \mathrm{g} \\
\% \%\end{array}$ & - & - & 48 & $\begin{array}{r}307 \\
86\end{array}$ & 106 & $\begin{array}{r}471 \\
82\end{array}$ & 96 & $\begin{array}{r}701 \\
88\end{array}$ & 24 & $\begin{array}{r}461 \\
95\end{array}$ & 3.4 \\
\hline $\begin{array}{l}\text { Subcutaneous fat } \\
\text { nmol/g } \\
\%\end{array}$ & - & - & 624 & $\begin{array}{r}115 \\
16\end{array}$ & 1,920 & $\begin{array}{r}471 \\
20\end{array}$ & - & 二 & 3,178 & $\begin{array}{r}298 \\
9\end{array}$ & 7.5 \\
\hline $\begin{array}{c}\text { Muscles } \\
\text { nmol/g } \\
\% \%\end{array}$ & - & - & 38 & $\begin{array}{l}53 \\
58\end{array}$ & 29 & $\begin{array}{r}154 \\
84\end{array}$ & 48 & $\begin{array}{r}240 \\
83\end{array}$ & 14 & $\begin{array}{r}144 \\
91\end{array}$ & 32.8 \\
\hline $\begin{array}{c}\text { Cerebrum } \\
\text { nmol/g } \\
\%\end{array}$ & - & - & 34 & $\begin{array}{l}86 \\
72\end{array}$ & 72 & $\begin{array}{r}115 \\
62\end{array}$ & 67 & $\begin{array}{r}202 \\
75\end{array}$ & 19 & $\begin{array}{r}106 \\
85\end{array}$ & 6.7 \\
\hline $\begin{array}{l}\text { Blood } \\
\text { nmol } / \mathrm{g} \\
\% \%\end{array}$ & 38 & $\begin{array}{l}77 \\
67\end{array}$ & 29 & $\begin{array}{r}134 \\
82\end{array}$ & 53 & $\begin{array}{r}192 \\
78\end{array}$ & 77 & $\begin{array}{r}298 \\
79\end{array}$ & 19 & $\begin{array}{r}259 \\
93\end{array}$ & 3.1 \\
\hline
\end{tabular}

a $S D=\left\{\left[\Sigma D^{2}{ }_{12}-\left(\Sigma D_{12}\right)^{2} / n\right]+\left[\Sigma D^{2}{ }_{23}-\left(\Sigma D_{23}\right)^{2} / n\right]+\left[\Sigma D^{2}{ }_{13}-\left(\Sigma D_{13}\right)^{2 / n}\right]\right\}^{1 / 2 /[}[6(n-1)]^{1 / 2}$. 
The assays were made with a liquid scintillation counter (Tri Carb 3002, Packard). Each sample was measured in two cycles either lasting $50 \mathrm{~min}$ or comprising a maximum of 50,000 impulses. The activity value for each individual assay was calculated as the mean value of these two determinations. The results are reported as the mean value of the two samples. The error of the method for the scintillation counter was $\pm 0.7 \%$ at 50,000 impulses. The error of the method was calculated for each organ and tissue according to the method for double determinations with systematic difference.

After the rats had been killed, it took about $15 \mathrm{~min}$ before all the organ and tissue samples had been transferred to sealed scintillation vials. So that it could be determined whether any styrene had evaporated from the samples into the ambient air during this period, a rat was exposed to styrene for $2 \mathrm{~h}$ with the previously described procedure. Samples were taken from different organs and tissues at the following three times: immediately after, $10 \mathrm{~min}$ after and $20 \mathrm{~min}$ after the rat was killed. The concentrations of styrene in the samples at the times cited did not differ significantly during the 20 -min period of observation. Thus styrene did not evaporate in measurable quantities from the examined organs during the 15min preparation period.

To get an idea of the ratio between unmetabolized and metabolized styrene in the organs and tissues, a supplementary study was performed. A total of five male rats (Sprague-Dawley, $200 \mathrm{~g}$ ) were utilized in this study. The animals were exposed to radioactively labeled styrene $\left(7-{ }^{14} \mathrm{C}\right)$ for $0.25-8 \mathrm{~h}$ in the same way as already described, with one rat at each exposure time (table 2). The specific activity was 0.18 $\mathrm{mCi} / \mathrm{mmol}$, and the air mixture contained $1,014 \pm 90$ (SD) $\mathrm{mg} / \mathrm{m}^{3}(240 \mathrm{ppm})$ of styrene. Organ and tissue samples were isolated from the liver, subcutaneous fat, muscles, cerebrum and arterial blood for the assay of the total content of styrene and its metabolites. The assays were made with liquid scintillation counting as already described.

The concentration of unmetabolized styrene in the arterial blood was determined with a head-space method (1). The content of unmetabolized styrene in the organs and other tissues was determined with gas chromatography after evaporation into nitrogen at $150^{\circ} \mathrm{C} \mathrm{(7).} \mathrm{Three} \mathrm{sam-}$ ples were taken from each organ and tissue, and the results are reported as the mean value of the three samples. The error of the method was calculated for each organ and tissue according to the method for triple determinations with systematic difference.

\section{Results}

In fig 1 the concentration of styrene and its metabolites (styrene equivalents) is shown immediately after the conclusion of exposure. The concentration of styrene in the subcutaneous fat displayed a sharp rise during the first $4 \mathrm{~h}$ of exposure when compared to that during the following $4 \mathrm{~h}$. After $4 \mathrm{~h}$ of exposure, the subcutaneous fat contained $200 \mathrm{nmol}$ of styrene equivalents/g of tissue. After $8 \mathrm{~h}$ of exposure,

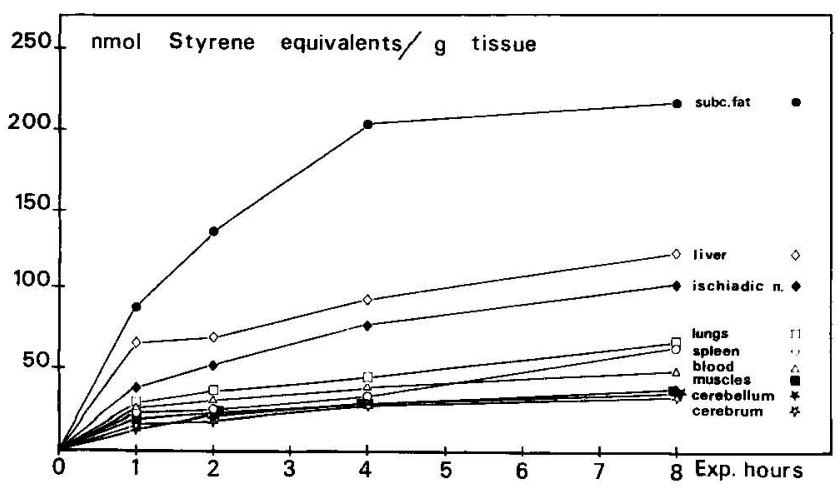

Fig 1. Organ and tissue concentrations of styrene equivalents (styrene and its metabolites) in rat immediately after the conclusion of exposure as a function of the exposure duration in hours. The animals were exposed to a styrene concentration of $184 \mathrm{mg} / \mathrm{m}^{3}$ (43.5 ppm). (subc. = subcutaneous, n. = nerve) 


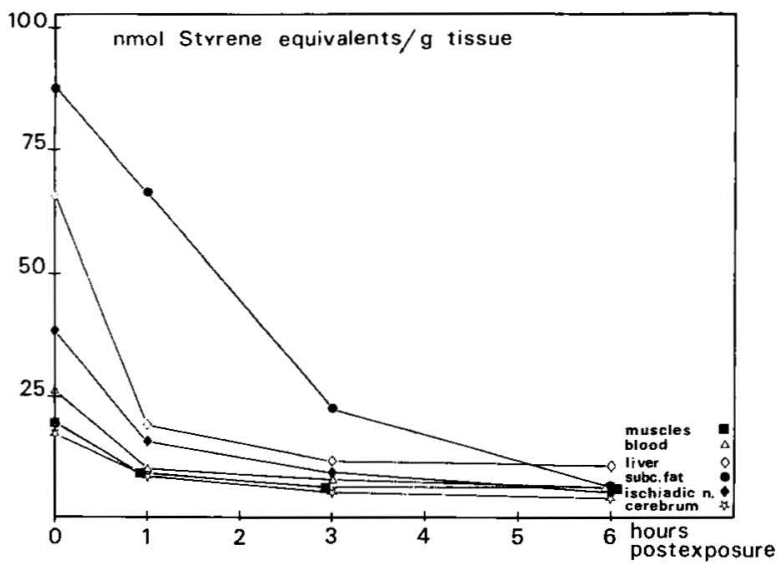

Fig 2. Organ and tissue concentrations of styrene equivalents (styrene and its metabolites) in rat as a function of the time elapsed after the conclusion of exposure. The animals were exposed to a styrene concentration of $184 \mathrm{mg} / \mathrm{m}^{3}$ (43.5 ppm) for 1 h. (subc. = subcutaneous, n. = nerve)

the concentration was $216 \mathrm{nmol}$ of styrene equivalents/g of tissue.

After $1 \mathrm{~h}$ of exposure the liver contained $65 \mathrm{nmol}$ of styrene equivalents/g of tissue. After $8 \mathrm{~h}$ of exposure the concentration had increased to $123 \mathrm{nmol} / \mathrm{g}$. The concentration in the ischiadic nerve following $8 \mathrm{~h}$ of exposure was $103 \mathrm{nmol}$ of styrene equivalents/g of tissue. The corresponding value for the cerebrum was $34 \mathrm{nmol}$. The concentration of styrene equivalents in the cerebrum, cerebellum and muscles paralleled the arterial blood concentration throughout the entire period of exposure and amounted to about $70 \%$ of the arterial blood value. The lungs and spleen contained 68 and $63 \mathrm{nmol}$ of styrene equivalents/g of tissue, respectively, following $8 \mathrm{~h}$ of exposure, whereas the concentration in the arterial blood at the same time was 49. Throughout the entire period of exposure, the kidneys displayed high concentrations of styrene equivalents with a value of $728 \mathrm{nmol} / \mathrm{g}$ after $8 \mathrm{~h}$ of exposure.
The concentrations during a $6-\mathrm{h}$ decay period following an initial exposure to styrene for $1 \mathrm{~h}$ are shown in fig 2 . The concentrations in the cerebrum, cerebellum and muscles paralleled the blood concentration also during the decay phase and amounted to about $70 \%$ of the blood value. After a 1-h decay phase, the concentration in the liver was relatively constant. The subcutaneous fat contained a'bout $8 \%$ of the initial value after the 6 -h decay phase. The half-time for styrene equivalents in the subcutaneous fat following $1 \mathrm{~h}$ of exposure was estimated to be $2.2 \mathrm{~h}$. The accumulation of styrene equivalents in the organs and tissues at the various exposure alternatives is described completely in taible 1 .

The relative concentration of metabolized styrene in relation to the total quantity of styrene and its metabolites, ie, styrene equivalents, is shown in fig 3 (supplementary study). After a period of exposure of $1 \mathrm{~h}$ or more, the liver contained.

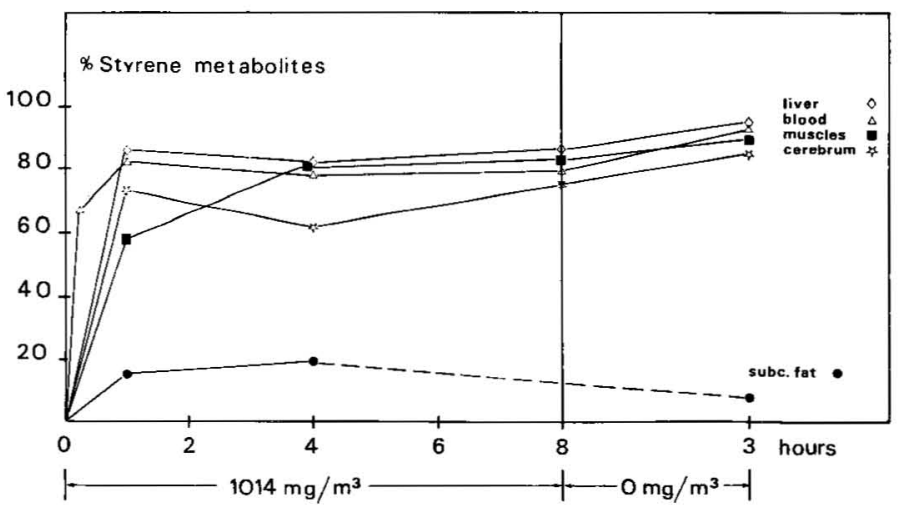

Fig 3. The concentration of metabolized styrene in rat, expressed as a percentage of the total quantity of styrene and its metabolites in different organs and tissues during an exposure lasting up to $8 \mathrm{~h}$, followed by a 3-h decay period. The animals were exposed to a styrene concentration of $1,014 \mathrm{mg} / \mathrm{m}^{3}$ (240 ppm). (subc. = subcutaneous) 
about $85 \%$ metabolites. After a 3-h decay period the percentage value increased to 95. The muscles and cerebrum contained high concentrations of metabolites, ranging from 58 to $91 \%$.

In the subcutaneous fat the metabolites amounted to $16-20 \%$ during exposure lasting up to $8 \mathrm{~h}$. It decreased to about $9 \% 3 \mathrm{~h}$ after the conclusion of exposure. Throughout the entire period of exposure, the proportion of metabolites in the arterial blood was high, about $80 \%$. It increased after a 3-h decay period to about $95 \%$.

The quotients between the concentration of unmetabolized styrene in subcutaneous fat and the concentration in blood or air was calculated. After $4 \mathrm{~h}$ of exposure the quotient was found to be 36 for subcutaneous fat/blood and 197 for subcutaneous fat/air. The accumulation of styrene and metabolites is listed completely in table 2 .

\section{Discussion}

Styrene is mainly metabolized in the liver. First, styrene is oxidized into styrene oxide by the microsomal monooxygenase system (10). Styrene oxide is further metabolized by hydration or conjugation, reactions which mainly take place in the liver, but also in the lungs, kidneys, intestinal mucosa and skin (15). The following diagram shows the proposed main pathways of styrene metabolism (12):

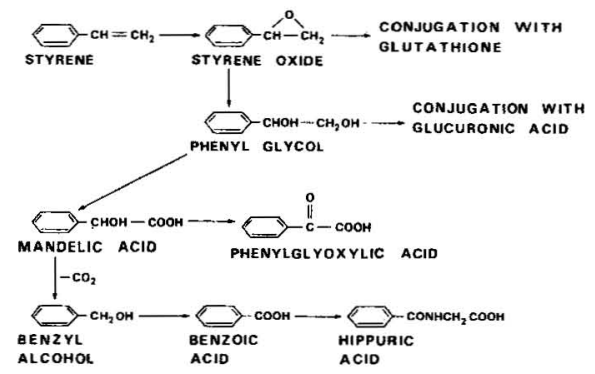

In the present styrene study a concentration of about $85 \mathrm{nmol}$ of styrene equivalents/g of tissue was found in subcutaneous fat after $1 \mathrm{~h}$ of exposure to approximately $44 \mathrm{ppm}$ of styrene (table 1 ). Alfter administering a single oral dose of radioactively labeled styrene $(192 \mathrm{nmol} / \mathrm{g}$ of body weight) to $400-\mathrm{g}$ male rats, Plotnick \& Weigel (13) found a concentration of $97 \mathrm{nmol}$ of styrene equivalents/g of subcutaneous fat. In exposure of man to 50 ppm of styrene for $2 \mathrm{~h}$ (7), the concentration of styrene in subcutaneous fat amounted to only $34 \mathrm{nmol} / \mathrm{g}$ after the conclusion of exposure.

The concentration of styrene equivalents in subcutaneous fat declined relatively quickly after exposure was concluded in the presen't study. The half-time for styrene equivalents in subcutaneous fat after $1 \mathrm{~h}$ of exposure was estimated to be $2.2 \mathrm{~h}$. Engström et al (7) estimated the half-time for styrene in the subcutaneous fat of man to be about $72 \mathrm{~h}$. Probably, both the distribution and the elimination of styrene to and from subcutaneous fat is faster in rat than in man. The reason may be a faster rate of energy metabolism per gram of tissue in rat which results in a greater blood perfusion per gram of tissue. Man also has a larger volume of subcutaneous fat than rat. The blood perfusion of subcutaneous fat in man declines as the volume of the tissue increases (11).

From the supplementary study the coefficient between the concentration of unmetabolized styrene in subcutaneous fat and inspiratory air after $4 \mathrm{~h}$ of exposure was calculated to be 197. This value is much lower than the one calculated from in vitro experiments with oil/air. van Rees (14) reported an oil/air partition coefficient of 4,100 for styrene. The reason for the different values is, above all, that the present study was undertaken in vivo and subcutaneous fat cannot be equated with oil.

The percentage of styrene metabolites in the liver was very high during exposure. It ranged from about 80 to $90 \%$ (table 2). In a corresponding supplementary study on xylene (5), the values ranged from about 50 to $65 \%$. Besides, the concentration of styrene equivalents in the liver was about three times higher (table 1) than that of xylene. Benid et al (3) added ${ }^{14} \mathrm{C}$-styrene oxide to isolated, perfused rat liver and showed that the biliary excretion of metabolites was dose-dependent, with a decrease at high doses. At a dose of $\mathbf{1 0}$ $\mu \mathrm{mol}$ of styrene oxide/liver, the biliary excretion accounted for $40 \%$ of the administered dose. Plotnick \& Weigel (13) showed that, after the oral administration 
of ${ }^{14} \mathrm{C}$-styrene to rats, fecal excretion accounted for less than $2 \%$ of the dose. The greater proportion of styrene metabolites than xylene metabolites in the liver could be explained by an enterohepatic circulation of styrene metabolites.

The percentage of styrene metabolites in the cerebrum ranged from about 60 to 75 during exposure and increased to $85 \%$ after the 3-h decay period. Savolainen \& Vainio (16) also found relatively high levels of styrene metabolites in the brain after an intraperitoneal injection of radioactive styrene or radioactive styrene oxide.

In previous studies no accumulation of styrene meta'bolites in subcutaneous fat has been found (4). The results irom our supplementary study indicate such an accumulation, ranging from about 15 to $20 \%$ during exposure. One possible explanation for this finding may be the presence of polar styrene metabolites in the water content of adipose tissue (8). However, before a final conclusion can be drawn, further investigation is needed, as the results are based on only one rat at each exposure time.

\section{Acknowledgment}

I wish to thank R Bjurström, BSc, for his kind cooperation and skillful technical assistance.

\section{References}

1. Astrand I, Ehrner-Samue1 H, Kilbom A, Ơvrum P. Toluene exposure: I. Concentration in alveolar air and blood at rest and during exercise. Work environ health 9 (1972) 119-130.

2. Bardodej Z, Bardodejova E. Biotransformation of ethyl benzene, styrene and alpha-methyl-styrene in man. Am ind hyg assoc j 31 (1970) 206-209.

3. Bend JR, Smith BR, van Anda J, Ryan AJ, Fouts JR. Biotransformation of styrene oxide by the isolated perfused rat liver and by subfractions of homogenized liver cells. In: Fouts JR, Gut I, ed. Industrial and environmental xenobiotics. Excerpta Medica, Amsterdam 1978, pp 62-70.

4. Bergman $\mathrm{K}$. Whole-body autoradiography and allied tracer techniques in distribution and elimination studies of some organic solvents: Benzene, toluene, xylene, styrene, methylene chloride, chloroform, carbon tetrachloride and trichloroethylene. Scand j work environ healith 5 (1979): suppl 1, $93-120$.

5. Carlsson A. Distribution and elimination of ${ }^{14} \mathrm{C}$-xylene in rat. Scand $\mathrm{j}$ work environ health 7 (1981) $51-55$.

6. Danishefsky I, Willhite M. The metabolism of styrene in the rat. $\mathrm{J}$ biol chem 211 (1954) $549-553$.

7. Engström J, Bjurström R, Åstrand I, Övrum $P$. Uptake, distribution and elimination of styrene in man: Concentration in subcutaneous adipose tissue. Scand $j$ work environ health 4 (1978) 315-323.

8. Garrow JS. Energy balance and obesity in man. Norith-Holland Publishing Co, Amsterdam, London 1974, pp 232-234.

9. Kalliokoski $P$, Pfäffli P. Charcoal sampling method for determining the concentration of styrene in air. Scand $j$ work environ health 1 (1975) 193-198.

10. Leibman $\mathrm{K}$, Ortiz E. Oxidation of styrene in liver microsomes. Biochem pharmacol 18 (1969) $552-554$.

11. Nielsen SL, Larsen OA. Relationship of subcutaneous adipose tissue blood flow to thickness of subcultaneous tissue and total body fat mass. Scand $\mathrm{j}$ clin lab invest 31 (1973) $383-388$

12. Ohtsuji $H$, Ikeda $M$. The metabolism of styrene in the rat and the stimulatory effect of phenobarbital. Toxicol appl pharmacol 18 (1971) 321-328.

13. Plotnick HB, Weigel WW. Tissue distribution and excretion of $14 \mathrm{C}$-styrene in male and female rats. Res commun chem pathol pharmacol 24 (1979) 515-524.

14. van Rees $H$. The partition coefficients of styrene between blood and air and between oil and blood. Int Arch Arbeitsmed 33 (1974) $39-47$.

15. Ryan AJ, James MO, Ben-Zvi Z, Law FCP, Bend JR. Hepatic and extrahepatic metabolism of ${ }^{14} \mathrm{C}$-styrene oxide. Environ health perspect 17 (1976) 135-144.

16. Savolainen $H$, Vainio $H$. Organ distribution and nervous system binding of styrene and styrene oxide. Toxicology 8 (1977) 135-141. 